\title{
Examining the Development of Banking Sector Regulations and Supervision Practices across BRICS and G7 Countries
}

\author{
Alam Ahmad $\mathbb{D}^{1},{ }^{1}$ Asif Khan $\mathbb{D}^{2},{ }^{2}$ Samreen Akhtar $\mathbb{D}^{1},{ }^{1}$ and Hafiz Wasim Akram ${ }^{3}{ }^{3}$ \\ ${ }^{1}$ Department of Finance and Economics, College of Administrative and Financial Sciences, Saudi Electronic University (SEU), \\ Riyadh 23447, Saudi Arabia \\ ${ }^{2}$ School of Business, University of Petroleum and Energy Science (UPES), Dehradun 248007, Uttarakhand, India \\ ${ }^{3}$ Department of Marketing \& Entrepreneurship, College of Commerce and Business Administration, Dhofar University, \\ Salalah, Oman
}

Correspondence should be addressed to Alam Ahmad; a.ahmad@seu.edu.sa

Received 11 September 2021; Revised 8 November 2021; Accepted 9 December 2021; Published 24 December 2021

Academic Editor: Faheem Aslam

Copyright ( 2021 Alam Ahmad et al. This is an open access article distributed under the Creative Commons Attribution License, which permits unrestricted use, distribution, and reproduction in any medium, provided the original work is properly cited.

\begin{abstract}
The study examines the development in the banking regulatory practices across BRICS nations over the period 2000-2019. The convergence and sustainability of the regulatory framework in BRICS nations to G7 norms have also been assessed. The analysis is based on five key regulatory measures, which include activity restrictions, entry requirements for a new bank, foreign bank entry restrictions, capital stringency, and deposit insurer powers. The study constructs the regulatory indexes based on the central bank responses to the Bank Regulation and Supervision Survey (BRSS) conducted by the World Bank. To estimate the indexes, the study follows Barth, Caprio, and Levine guidelines. The result reveals that the regulators of BRICS countries impose higher restrictions on bank activities than in the G7 nations. Furthermore, the United Kingdom and Brazilian bank regulators are more liberal and imposed fewer restrictions on insurance activity only. In addition, getting a bank license is tough in both regions. Regulators allow only fit and proper applicants into the banking domain. Furthermore, the authors find that the requirements for capital are becoming more restricted in BRICS nations between 2003 and 2019 to align with Basel capital accords, relative to G7 nations. The study documents a convergence in the banking licensing requirements, and limitations on foreign bank entry and official supervisory powers in the BRICS countries with the G7 nations. The study suggests that the regulators must offer freedom to banks' activities with increasing supervision, and it boosts the competition in the banking sector and enhances customer welfare. Furthermore, the policymakers need to redesign the deposit insurance mechanism and equip deposit insurers with more powers to enhance the safety of depositors' interests and minimize the moral hazards in the banking sector in both regions.
\end{abstract}

\section{Introduction}

Financial institutions are considered to be the most regulated entities, with banking being a heavily regulated industry around the world. However, the Global Financial Crisis (hereafter, GFC) 2007/08 has uncovered the weakness of the regulatory and supervisory mechanism of the banking system in developing and developed countries [1]. In addition, the liberal regulatory environment provokes a crisis, and the countries with strong regulatory and supervisory mechanism remain less affected during GFC [2]. The GFC forced the regulators across countries to revisit their regulatory and supervisory mechanism to achieve stable banking systems, with the objectives of limiting the bank fragility and promoting a stable and efficient banking system [3-5]. Furthermore, a well-designed bank regulatory and supervisory framework promotes the stability of the banking system [6] along with higher profitability of banks [3] which results in contribution to the welfare of the society [7]. In addition, a financially sound and efficient banking system plays a significant role in the growth of an economy [8].

The regulators issue guidelines for the banking operations and also monitor them. In particular, the banking activities, bank licensing requirement, foreign bank entry, capital adequacy norms, supervisory powers, and deposit 
insurance mechanism are the most crucial and monitored aspects of bank regulation and supervision framework [9]. If a bank is found guilty of not following the regulatory norms, consequently, the regulators may impose penalty and cancel the bank's license. Therefore, the banks must adhere to the regulatory guidelines to ensure compliance and smooth operations. Furthermore, developing and emerging markets have been more inclined than the advanced countries to employ effective regulatory mechanisms to achieve efficiency and stability in their financial system [10].

Over the last two decades, the bank regulation has emerged as the focal point of research in the bank literature, notably, the difference in banking regulatory and supervisory practices in developing and developed countries. Furthermore, banking systems around the world have seen significant changes in the regulatory standards [11]. The modern and globalized banking sector has prompted the think tanks of banking systems to promote a uniform and standard regulatory environment across the world [12]. In addition, the Bank Regulation and Supervisory Survey (afterwards, BRSS) conducted by the World Bank and published during the years 2001, 2003, 2007, 2011, and 2019 offer the cross-country data on bank regulatory and supervisory practices. It provides the opportunity for researchers and policy makers to analyze the bank regulatory frameworks. However, the literature on developing countries is still underexplored.

Over the recent decades, the regulators of BRICS countries like, Brazil, Russia, India, China, and South Africa have adopted more liberal financial policies with the expectation that removing regulatory impediments to competition will yield efficiency gains, limit bank fragility, and promote financial stability [13]. However, the literature suggests no conclusive evidences with regard to the regulatory practices that should be considered as "best-practice" for promoting the stability of the banking system in the fragile environment [9]. In line with the global trend, the banking markets in the emergent BRICS countries have undergone regulatory developments. In particular, the BRICS regulators have either amended the existing policies or introduced new regulatory policies in order to enhance bank stability, banking sector development, and the productivity of the banking systems. The regulatory practices in the G7 or G20 nations, particularly the banks operating practices, are considered as the benchmark for the other developing nations to follow $[14,15]$.

On the whole, recently, technological upgradation, global financial crisis, and integration of the banking sector across the globe induces the practitioners and policy-makers to revisit and focus more on the regulation and supervision framework of the banking sector. The literature, exploring the differences in the regulatory practices in developed and developing countries, has emerged as an interesting area to explore [3]. In addition, the study has also explored which regulatory practices work the best [16]. However, studies that explore the regulatory and supervisory practices in developing countries are scarce. In particular, studies scrutinizing the regulatory practices in detail, with special focus on BRICS nations are absent.
Therefore, the present study aims to assess developments in the regulatory and supervisory practices of the banking sector of Brazil, Russia, India, China, and South Africa during the period 2000-2019. In particular, the study considers five key regulatory measures, including bank activity restrictions, entry requirements for a new bank, foreign bank entry, capital stringency norms, and powers of deposit insurers to assess the regulatory adequacy in the BRICS banking markets. The regulatory indices have been constructed using five BRSS survey rounds conducted by the World Bank. Second, the study aims to examine the variations in the regulatory and supervisory practices adopted in BRICS and G7 nations. In particular, we examine whether regulatory practices across BRICS nations have converged toward the global best practices as defined by the G7 nations. In light of these objectives, this study addresses the following research questions: (i) What are the key differences in the bank regulatory standards adopted by BRICS nations? (ii) Are there regulatory gaps between BRICS and G7 nations? (iii) Have the regulatory gaps between BRICS and G7 nations widened or narrowed over the period 2000-2019? and (iv) Is there a convergence in the key regulations in the BRICS and the G7 nations?

The contributions of the study are manifold. First, the study provides insights into the banking structural and regulatory system in BRICS and G7 countries. In particular, the study uses the innovative approach of regulatory frameworks developed by Barth et al. [17] to analyze and compare the regulatory standards based on bank activity restrictions, entry requirement into banking system, foreign bank entry restrictions, capital adequacy norms, and deposit insurer power and its framework across BRICS and G7 nations. Second, the study uses the most trusted and relevant BRSS database to conduct the study (the World Bank Regulation and Supervisory Survey (BRSS) were designed and conducted by the World Bank research group to examine the bank regulatory and supervisory framework and its variation across the banking systems in the world). The present study uses the BRSS responses to construct the selected regulatory index and interpret them as guided in the survey manual. Therefore, the conclusions based on this study offer valid inputs for policy makings. Third, the study offers a wide angle of regulation based on selected indicators. The study is based on the BRSS responses, which was conducted by World Bank; its first round was released in the year 2001, which represents the year 1999, and the latest survey round, which was released in the year 2019, represents the year 2018. Therefore the study has selected the time period to examine the trends in the regulatory and supervisory practices and recent regulatory developments in the emerging countries like BRICS and compared them with the financially developed nations, and for benchmarking, we have selected the G7 nations. The previous studies in the literature have not focused on any individual country. For example, Ayadi et al. [18], Ambrocio et al. [19], Li and Li [20], and Barth et al. [9] focus on particular region collectively. The present study deeply analyses the regulatory environment of each member nation and compares it with its own region's regulatory average and the global 
benchmark, the G7 region, as well. Fourth, the study scrutinizes the convergence in the regulatory norms between BRICS and G7 nations over the period 2000-2019. The G7 nations are considered to have a well-developed financial system; therefore, bank regulatory and supervisory framework in these nations can be considered as the benchmark for other peer nations. Thus, the study compares and examines whether BRICS nations are moving toward best industry practices in terms of bank regulation or not? The authors are confident enough that the findings of this study will benefit the policy-makers and bank regulators to analyze the policies that work the best for BRICS countries. Furthermore, the central banks of a particular country, practitioners may redesign the regulatory framework based on the practices of benchmark countries in order to enhance the stability of banks, promote healthy competition, and raise efficiency and productivity of BRICS banking systems.

The rest of the paper is structured as follows. Section 2 provides the relevant literature review. Section 3 presents the overview of the banking systems in the BRICS nations. Section 4 describes the methodological framework for constructing regulatory indicators used in the present study. Section 5 presents the empirical results. The discussion based on the empirical findings is provided in Section 6. The conclusions and policy recommendations have been discussed in Section 7. The limitations of study and directions for the future research have been provided in the last section of the study.

\section{Relevant Literature Review}

During the last two decades, particularly, after the first round of BRSS survey launched in the year 1999, the researcher attempted to examine the regulatory and supervisory developments in the banking system around the word (see Barth et al. [21], Demirgüç-Kunt and Detragiache [22], Anginer et al. [23], Čihák, et al. [2], Barth et al. [9], among others). Recently, the researcher has also shown interest in empirically testing the association between regulation and other dimensions of the banking industry. For example, association between bank regulation and efficiency (Noor et al. [24], Li, [25], Dudchenko et al. [26], Chortareas et al. [15], Djalilov and Piesse [3], Triki et al. [16]), bank regulation and level of completion (Li, [25], Hakenes and Schnabel [27], Degryse and Ongena [28], Agoraki et al. [29], Yin [30]), bank regulation and financial stability of banks (Anarfo et al. [31], Schnabl and Sonnenberg [32], Fraccaroli et al. [33]), and bank regulation and risk-taking behavior (Brandao-Marques et al. [34], Bartholdy and Justesen [35] 2021, Louhichi et al. [36], Hilscher et al. [37]) were a few focus areas which are also being scrutinized in the bank regulation literature. Furthermore, Figure 1 represents the research trend in bank regulation and supervision literature (see Additional Points). It reflects that the first round of BRSS survey, which was released in the year 2001. It motivated the researchers to scrutinize the bank regulatory practices across the developing and developed countries. In addition, the study observes that the GFC 2007/08 also triggered the interest of researchers to study the variation in regulation, impact of crisis on the banking sector, and the resilience of the regulatory and supervisory framework across the world.

The empirical studies on the subject matter primarily focus on the testing of a theoretical proposition that a better regulatory and supervisory framework promotes a stable banking system with efficiency and transparent banking operations. In the literature, all the significant regulatory dimensions, like activity restrictions, entry into the banking system, capital adequacy norms, deposit insurance mechanism, foreign bank entry, and document requirement for banking license along with their impact on the banking environment have been have scrutinized. For example, Barth et al. [9] in their seminal research work observed that restriction on bank activity may hamper the bank's stability. However, the income diversification enhances the banks' stability and performance. Furthermore, they observe that the restrictions on foreign bank entry are positively associated with the banking system fragility. The study also observes that the liberal deposit insurance framework may reduce bank stability. Similarly, Barth et al. [38] note that government share in bank ownership is negatively associated with the desired banking sector performance. The regulation pertaining to entry and exit into the banking system also attracted the researchers. The study also showed an interest to scrutinize the association between the entry and exit requirements and level of competition in the banking sector. Demirgüç-Kunt and Martínez Pería [39] also argue that the banking system with high entry and exit regulation reduces the competition level in the banking system. Another researcher, Li [40] assesses the impact of bank regulatory practices on the competition level in the banking sector. By analyzing the data of banks operating in 23 emerging economies during 1996-2016, they found that lower restriction on the entry of foreign banks and liberal environment for bank activities leads to a healthy competition in the banking sector. Gulati [41] notes that the bank entry requirements in BRICS countries have liberalized over time. However, the author argues that with the increased government ownership in the banking sector, the competition level has been reduced in spite of liberal bank entry regulation, specifically in the Indian banking sector.

Furthermore, regulators can place restrictions on bank's activities, for example, bank engagement insecurities, insurance, and real estate activities. The literature also scrutinized and reported a mix of evidences on bank activity restrictions and its impact on bank's financial performance, stability, and competition in the banking industry. In particular, Gulati [41] argues that Indian regulators imposed maximum restrictions on bank activities and debarred the banks from owning nonfinancial business, which could lead to unhealthy competition in the financial sector. Recently, Ashraf et al. [42] note that the countries that imposed higher restrictions on bank activities are less risky. Similar observations were reported by $\mathrm{Li}$ [40]. Furthermore, Yin [43] reports that developing countries impose more restrictions on bank activities than developed nations. The author also cites that the weaker supervisory mechanism in developing nations is one of the key factors behind the more number of restrictions on bank activities. 


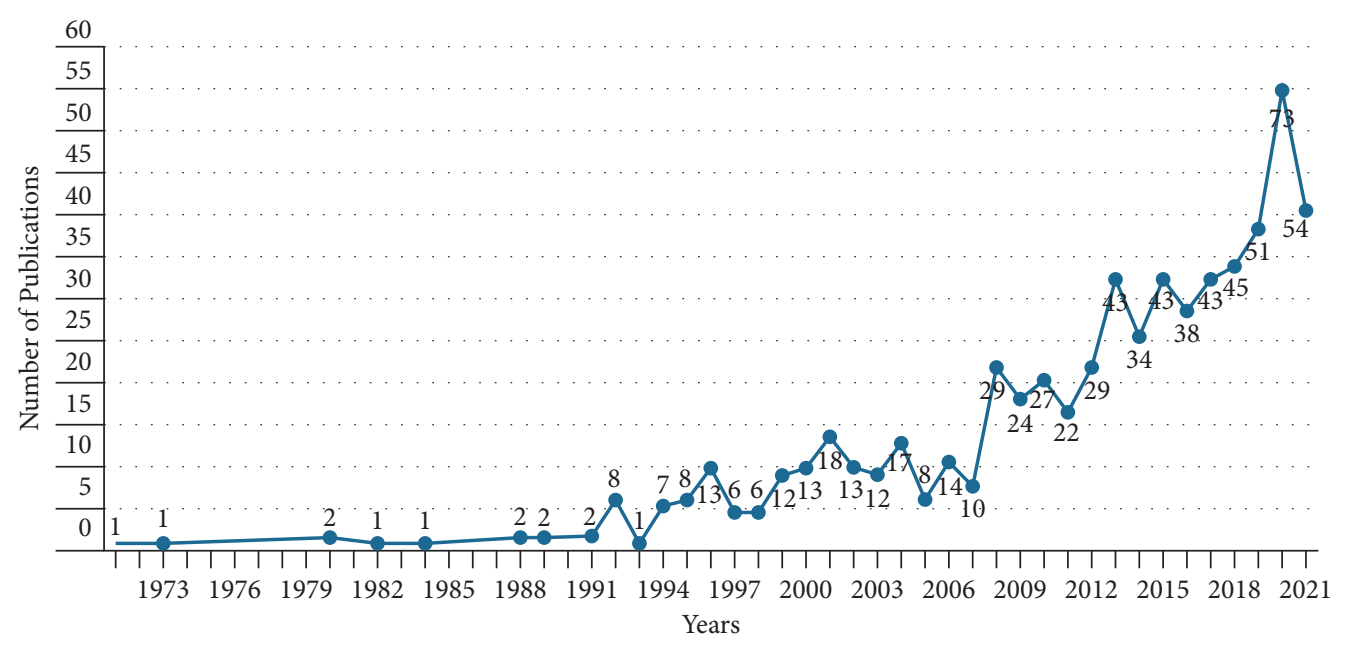

Figure 1: Trends in research publications.

The capital regulation is one of the most prudential regulations in the banking sector around the world [19]. Particularly, the GFC 2007/08 raised the concern for effective capital regulation to promote banking sector stability and robustness. In this direction, the Basel Committee on Bank Supervision placed more requirements in terms of quality and quantity of bank capital as per the Basel III Accord [10]. Ashraf et al. [42] report that the rigorous capital requirement ensures the lower level of bank default risk. In addition, Carletti et al. [44] observe that stringent bank capital may reduce the volatility in the banking sector.

Furthermore, the banking sector's stability was also determined by the stringency of the bank supervisory mechanism. The absence of effective supervisory powers increases the probability of bank defaults. He et al. [45] document that the stronger supervisory powers promote banks to lend smaller loans with more restrictive loan covenant. Furthermore, they conclude that the powerful bank supervisory mechanism also affects the banks' risktaking behavior in the lending process. Avgeri et al. [46] confirm that the strong supervisory powers are positively associated with the bank's profitability. The literature has also established the relationship between bank regulation and performance of banks in developing and developed countries [3,38]. Recently, $\mathrm{Li}$ and $\mathrm{Li}[20]$ examine the association among bank regulation, competition, and performance level of banks. Their results suggest that the robust official supervisory power, stringent activity restrictions, and liberal requirements in terms of bank's capital led to the higher performance levels.

Literature has ample evidence that suggests that bank regulation and supervision mechanism significantly affect the bank's risk-taking behavior, profitability, banking sector stability, level of competition, etc. In addition, studies focusing on examining the dimensions of bank regulation of a particular country are scarce. Most authors study the bank regulatory framework on an aggregate basis. For example, Demirgüç-Kunt and Detragiache [22] studied the policies of 180 banks related to regulatory and supervisory framework and observed the heterogeneity in the bank practices across the nations. Furthermore, Ayadi et al. [18] examined the differences in bank regulatory practices among Southern and Eastern Mediterranean countries (SEMCs) and their convergence with the regulations in the EU-Mediterranean area. The study finds few weak areas of deposit insurance, entry requirement into banking sector along with the interference from political parties.

After a thorough review of literature, the authors note that the existing studies on bank regulation and supervision have addressed the concerns in a broader context and have provided more generalized findings. However, empirical studies that focus on comparing the bank regulatory developments in the emerging nations are scarce. The present study is an attempt in this direction and aims to contribute to the growing literature. In particular, the present study focuses on scrutinizing the developments in the regulatory practices across BRICS nations and testing their convergence to the global standards practices.

\section{Overview of BRICS Banking Sector}

This section highlights some stylized facts of banking industry in the BRICS countries. In recent years, the banking sector in the BRICS countries has developed at a faster pace [13]. Table 1 shows that the banking sectors of BRICS countries are dominated by domestic banks, and there are noticeable disparities among these countries. In Brazil and South Africa, the share of banking assets with foreign banks is around 25 percent, which is much higher than China and India. We also note that the availability of financial services remain significantly low in the Indian financial system, while Brazil breaks all the records in terms of the number of ATMs per 1,00,000 adults. Recently, Russia came forward and moved closely with Brazil in terms of ATMs per 1,00,000 adults. The concentration in the banking sector in South Africa is significantly high which represents the oligopoly in the financial system. The growing deposit money bank assets (percentage of GDP) reflect the importance and growth in the size of the financial system (Table 1). However, the size of the retail banking assets varies significantly across the BRICS 
TABLE 1: Stylizedfact of banking sector structure in across BRICS nations (2007-2017).

\begin{tabular}{|c|c|c|c|c|c|c|c|c|c|c|c|c|}
\hline Country & Indicator & 2007 & 2008 & 2009 & 2010 & 2011 & 2012 & 2013 & 2014 & 2015 & 2016 & 2017 \\
\hline \multirow{5}{*}{ Brazil } & 5-bank asset concentration & 61.81 & 62.54 & 77.20 & 76.26 & 75.95 & 76.62 & 77.45 & 79.50 & 83.44 & 84.99 & 83.37 \\
\hline & ATMs per 100,000 adults & 109.44 & 111.95 & 114.50 & 118.18 & 116.44 & 115.50 & 118.59 & 118.08 & 115.11 & 112.23 & 107.96 \\
\hline & Bank $Z$-score & 17.49 & 17.51 & 16.94 & 15.18 & 14.50 & 13.03 & 12.51 & 12.85 & 15.43 & 15.47 & 15.24 \\
\hline & $\begin{array}{c}\text { Deposit money banks" assets } \\
\text { to GDP (\%) }\end{array}$ & 73.04 & 75.82 & 80.28 & 80.51 & 87.03 & 92.65 & 94.65 & 95.85 & 102.33 & 105.75 & 105.26 \\
\hline & $\begin{array}{l}\text { Domestic credit to private } \\
\text { sector (\% of GDP) }\end{array}$ & 40.69 & 45.78 & 47.49 & 52.76 & 58.08 & 62.52 & 64.23 & 66.03 & 66.83 & 62.19 & 59.77 \\
\hline \multirow{5}{*}{ China } & 5-bank asset concentration & & & 69.98 & 67.05 & 64.68 & & & 55.38 & & 52.92 & 52.48 \\
\hline & ATMs per $100,000 \mathrm{a}$ & 11.91 & 15.49 & 19.70 & 24.67 & 30.17 & & & 54.75 & 76.79 & 81.45 & 84.16 \\
\hline & Bank $Z$-score & 20.37 & 18.41 & 17.13 & 19.17 & 18.58 & 19.44 & 19.84 & 20.51 & 23.00 & 21.19 & 22.93 \\
\hline & $\begin{array}{c}\text { Deposit money banks" assets } \\
\text { to GDP (\%) }\end{array}$ & 105.76 & 106.66 & 117.64 & 125.55 & 125.95 & 129.63 & 135.10 & 141.90 & 152.89 & 168.16 & 174.54 \\
\hline & $\begin{array}{l}\text { Domestic credit to private } \\
\text { sector (\% of GDP) }\end{array}$ & 105.79 & 102.00 & 124.41 & 126.58 & 123.10 & 128.92 & 134.32 & 140.74 & 153.23 & 157.57 & 157.02 \\
\hline \multirow{5}{*}{ India } & 5-bank asset concentration & 42.28 & & 41.18 & 39.86 & 39.89 & 39.37 & 39.48 & 40.17 & & 44.29 & 47.03 \\
\hline & ATMs per 100,000 adults & & & 05.31 & 7.27 & & & & & & & 22.07 \\
\hline & Bank Z-score & & & 16.75 & 17.28 & 16.98 & 17.12 & & 16.54 & 16.46 & 17.56 & 15.96 \\
\hline & $\begin{array}{c}\text { Deposit money banks" assets } \\
\text { to GDP (\%) }\end{array}$ & 57.72 & 62.42 & 63.44 & 62.24 & 66.04 & 67.34 & 68.71 & 68.68 & 68.67 & 69.77 & 68.35 \\
\hline & $\begin{array}{c}\text { Domestic credit to private } \\
\text { sector (\% of GDP) }\end{array}$ & 45.63 & 49.56 & 48.12 & 50.56 & 51.29 & 51.89 & 52.39 & 51.88 & 51.87 & 49.19 & 48.78 \\
\hline \multirow{5}{*}{$\begin{array}{l}\text { Russian } \\
\text { Federation }\end{array}$} & 5-bank asset conce & & & & & & & & & & & \\
\hline & ATMs per 100,000 adults & 45.02 & 61.61 & 72.39 & 95.54 & 116.89 & 142.00 & 156.51 & 185.32 & 172.65 & 168.75 & 163.98 \\
\hline & Bank $Z$-score & 07.97 & 08.08 & 06.29 & 07.43 & 07.61 & 06.96 & 06.97 & 06.46 & 05.65 & 05.92 & 06.97 \\
\hline & $\begin{array}{c}\text { Deposit money banks" assets } \\
\text { to GDP (\%) }\end{array}$ & 2.32 & 02.02 & 02.76 & 03.35 & 03.90 & 04.08 & 04.38 & 30.94 & 61.96 & 61.74 & 58.08 \\
\hline & $\begin{array}{c}\text { Domestic credit to private } \\
\text { sector (\% of GDP) }\end{array}$ & 37.78 & 41.55 & 45.26 & 42.84 & 41.58 & 43.88 & 47.93 & 56.03 & 57.33 & 52.86 & 77.90 \\
\hline \multirow{5}{*}{ South Africa } & 5-bank asset concentration & 98.99 & 98.86 & 98.71 & 99.41 & & & & 99.11 & & 98.84 & 98.47 \\
\hline & ATMs per 100,000 adults & 29.85 & 42.78 & 51.03 & 55.52 & 57.46 & & & 65.70 & 68.97 & 69.16 & 67.93 \\
\hline & Bank $Z$-score & 12.73 & 11.71 & 12.64 & 13.42 & 14.06 & 15.20 & 14.20 & 14.11 & 13.76 & 14.91 & 16.68 \\
\hline & $\begin{array}{c}\text { Deposit money banks" assets } \\
\text { to GDP (\%) }\end{array}$ & 77.03 & 81.50 & 83.81 & 79.84 & 77.11 & 77.25 & 76.36 & 76.73 & 77.66 & 78.52 & 77.97 \\
\hline & $\begin{array}{l}\text { Domestic credit to private } \\
\text { sector (\% of GDP) }\end{array}$ & 160.13 & 140.35 & 145.94 & 148.98 & 139.60 & 146.48 & 149.23 & 150.97 & 147.46 & 144.11 & 147.53 \\
\hline
\end{tabular}

Source: Global Financial Development Database, World Bank, available at https://www.worldbank.org/en/publication/gfdr/data/global-financialdevelopment-database.

nations. China has the largest retail banking sector in the region. Till 2009, the domestic banking asset to GDP in Brazil was at par with South Africa, but has shown a tremendous improvement in later years. Russia has a relatively small retail banking sector and growth was faster, but the crisis has slowed the progress. India's banking assets amounts to about 70 percent of GDP, which is half the contribution of the Chinese banking industry. The banking sector of India did not feel the shock much, and was able to maintain the speed of growth.

From the supply side, the evolution of domestic credit for the private sector, which remained almost the same among India, Russia, and Brazil up until 2006-2007, has risen with Brazil growing faster than its peers. China and South Africa stand out when it comes to domestic credit particularly for the private sector. However, there was a significant decline in the credit growth in China during the period 2004-2008, mainly due to instability in economic activities, but the situation stabilized afterwards. Furthermore, we find higher competition level in the banking system in India, Germany, South Africa, Canada, and France (see Figure 2). Moreover, a higher bank Z-score signifies lesser probability of insolvency of the banking system. The authors find that the banking system of China is likely to be more stable, and the Russian banking system is more prone to insolvency (see Table 1 and Figure 3). Zhang et al. [47] also find similar evidence. The favorable macroeconomic environment, the investment in private sector, and the improved quality of banks' loan portfolio till 2009 induced a significant credit growth in the financial system.

\section{Database and Methodology}

4.1. Sources of Data and Information. The five rounds (i.e., 2001, 2003, 2007, 2011, and 2019) of World Bank Survey: Bank Regulation and Supervision Surveys (BRSS) are the main sources of data and information used for constructing the regulatory indices. Furthermore, the rounds of the survey are based on the responses by national 


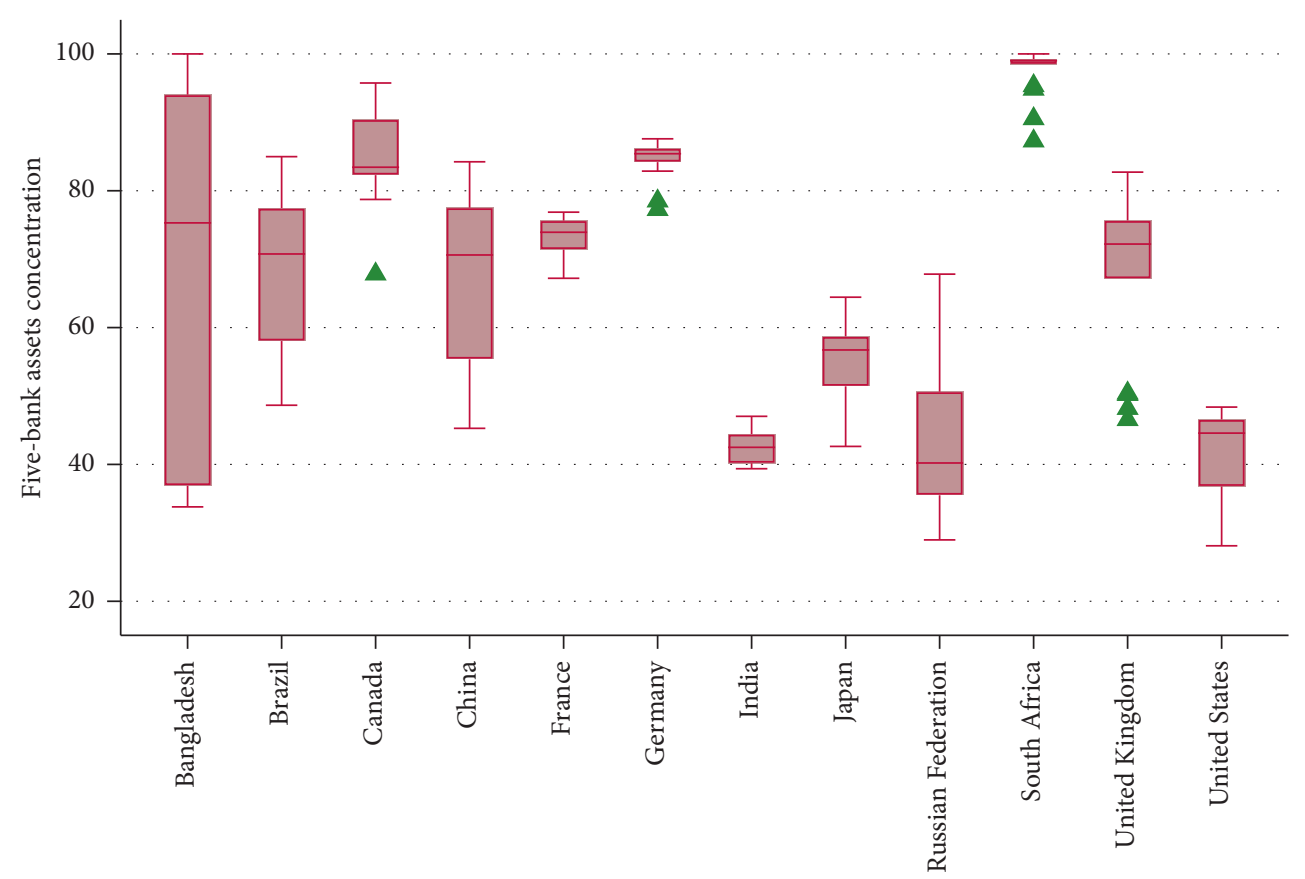

Figure 2: Boxplot-five bank asset concentration (2000-2017).

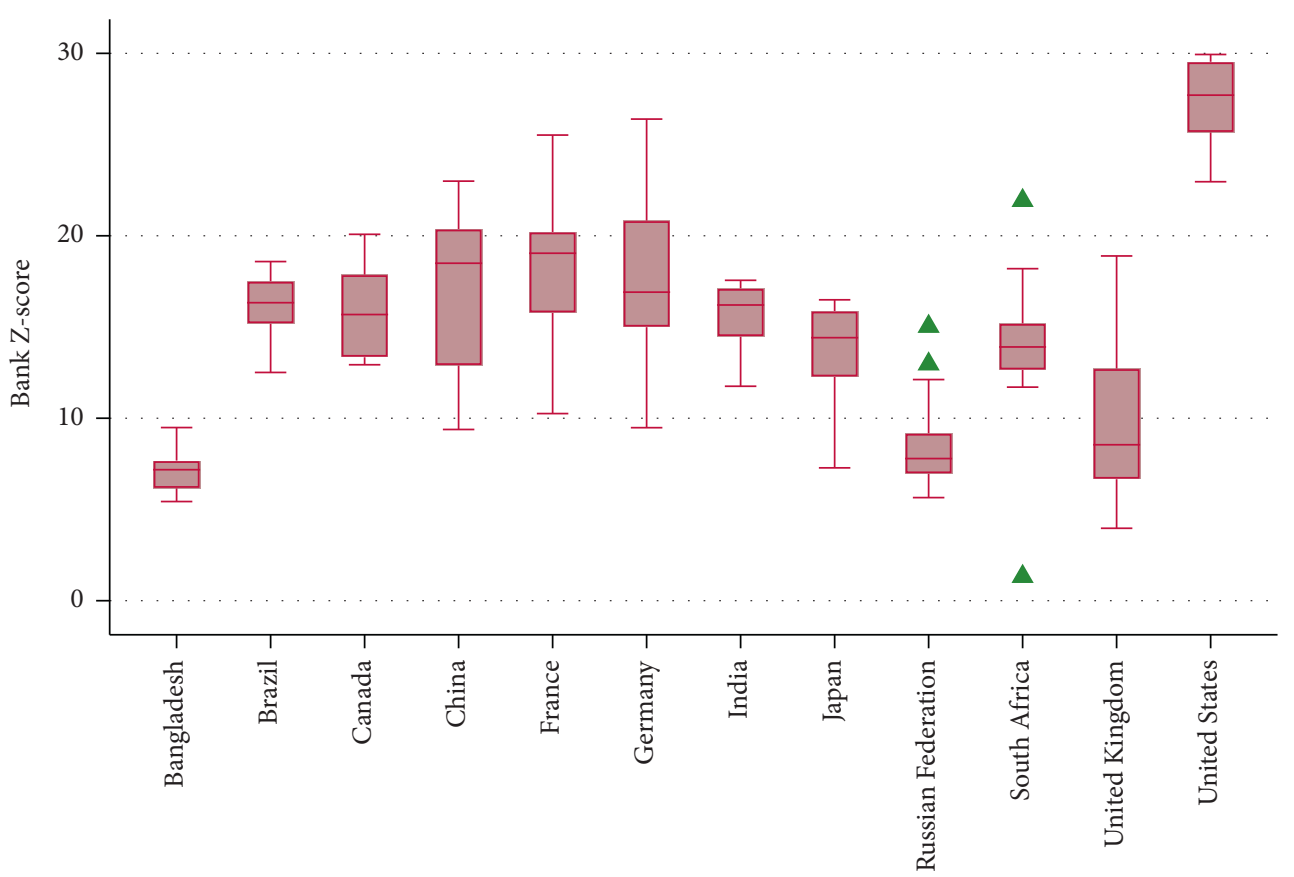

Figure 3: Boxplot-bank $Z$-scores (2000-2017).

regulators to the set of the questions on different regulatory and supervisory dimensions. The metadata on the surveys are summarized in Table 2 . One of the key advantages of this database: the patterns of questions do not change frequently during all the survey rounds. In addition, the latest survey covers few additional regulatory and supervisory areas. To avoid any inconsistencies, the study follows Barth et al.'s [17] approach to fill missing responses in Surveys I, II, and III based on responses to earlier surveys. However, the empty responses in Survey IV are filled in with zero, since the authors assume that the global financial crisis may have impacted the regulatory environment in the respective countries.

4.2. Composite Regulatory Indices. After a thorough review of literature, the authors observe that entry requirement into banking, restrictions on bank activity, capital norms, and deposit insurer powers were the most common and significant areas of regulatory supervisory dimensions. 
TABLE 2: Details on banking regulation and supervision surveys.

\begin{tabular}{lcccccc}
\hline BRSS & $\begin{array}{c}\text { Year in which } \\
\text { survey was } \\
\text { conducted }\end{array}$ & $\begin{array}{c}\text { Representing } \\
\text { year }\end{array}$ & $\begin{array}{c}\text { Published } \\
\text { year }\end{array}$ & $\begin{array}{c}\text { No. of countries } \\
\text { covered in the } \\
\text { survey }\end{array}$ & $\begin{array}{c}\text { No. of countries } \\
\text { that responded } \\
\text { to the survey }\end{array}$ & No. of questions covered in the survey \\
\hline Survey I & 1999 & 1999 & 2001 & 118 & 170 & 300 \\
Survey II & 2003 & 2002 & 2003 & 151 & 168 & 400 \\
Survey III & 2007 & $2005-2006$ & 2007 & 143 & 173 & 400 \\
Survey IV & 2011 & $2011-2012$ & 2013 & 142 & 143 & 630 \\
Survey V & 2019 & $2011-2016$ & 2019 & 160 & 160 & 719 \\
\hline
\end{tabular}

Note: number of countries covered in the survey represents complete cases (lower bound) and no. of countries responded for the survey represents all the cases where at least one answer was given (upper bound). Source: BRSS, World Bank.

Furthermore, Barth et al. [9] (i.e., member of the World Bank research group) who designed the BRSS survey, focused on the dimensions. Therefore, using Barth et al. [17] methodology, the study estimates the five key regulatory indices pertaining to (i) activity restrictions, (ii) bank entry requirements, (iii) restrictions on foreign bank entry, (iv) capital norms, and (v) power of deposit insurer for five different survey rounds (2001, 2003, 2007, 2011, and 2019). The description of each regulatory indicator and the selected question taken into account to calculate the index is given in Table 3. Following the BRSS database and methodology, the study grouped the responses to particular questions into an aggregate index "All Average Scaled Index" for each regulatory area (see Barth et al. [17] for more details). Using each country's average scaled index, the percent restriction in each regulatory area is calculated as

$$
\mathrm{RI}_{c}=\frac{\sum R_{c i}}{\mathrm{MR}_{c}} \times 100
$$

where, $\mathrm{RI}_{c}=$ regulatory index for $c^{\text {th }}$ category, $R_{c i}=$ restriction in $c^{\text {th }}$ category of regulation for $i^{\text {th }}$ country, and $\mathrm{MR}_{c}=$ maximum restriction in the $c^{\text {th }}$ category of regulation.

The process of calculating the regulatory index is based on Barth et al. [17]. All the studies based on the BRSS dataset followed the abovementioned formula to estimate the restrictions of particular regulatory dimensions. The core researchers, who designed the survey, suggested the same formula which we have used in our study. As per the literature and World Bank researchers' guidelines, this is the most suitable way to calculate the regulatory index based on the BRSS survey responses.

\section{Empirical Results}

\subsection{Regulatory Standards in BRICS and G7 Nations}

5.1.1. Activity Restrictions Index. Activity restriction index ranges from 1 (unrestricted) to 4 (prohibited). The study converts the index into percent of maximum score, in order to make the index more comparable. Figure 4 visualizes the changes in the bank activity restriction in each country across the BRICS and G7 nations over the period 2000-2019. It has been observed that, in terms of activity restrictions, China and India have highly regulated banking systems, and Russia and Brazil have the least regulated banking systems in the BRICS region. Earlier, the real estate activities were mostly regulated for banks, but more recently, owning nonfinancial firms have been restricted to a large extent in the BRICS region. Except China, the activities related to securities are the least controlled in the BRICS countries. Brazilian regulators imposed fewer restrictions on insurance activities, and completely allowed for real estate, securities, and ownership in nonfinancial firms. The bank regulators in Russia imposed few restrictions on insurance, real estate, and bank owning nonfinancial firms, and provided complete freedom on securities activities. Chinese and Indian banks had a complete ban on owing nonfinancial firms and activities related to real estate during the study period. South Africa puts fewer restrictions on real estate, securities and insurance-related activities. The G7 countries imposed more restrictions on real estate and insurance activities; however, they liberalized securities-related activities in the banking sector. Furthermore, the US banking system remained the most regulated, and prohibited to own nonfinancial firms and involve in real estate activities. On the other hand, the UK banking sector is the least restricted and placed few restrictions only on insurance activities, although banks are away from restriction on real estate, ownership in nonfinancial firm, and securities-related activities.

5.1.2. Bank Entry Requirements. The bank entry requirement index is estimated based on the different documents required to get the bank license. The index rages from 0 (most liberal) to 8 (most restricted) based on the bank entry restrictions. The study has converted the index into percentage to make it more comparable. The bank entry restriction indexes are presented in Figure 5. The authors note that Brazil, India, and Russia have moved toward global standards of granting the banking license by 2019. However, bank regulators in China do not require the banks to submit "background or experience of future managers" at the time of application for license. All regulators demand for Draft by Laws, but the regulator in South Africa does not require getting bank entry permission. Furthermore, to get banking license, national regulators in G7 countries require all the eight legal documents. Unfortunately, Japan has not responded to Survey IV. However, based on previous survey responses, Japanese regulators also require all the documents except "business or marketing strategy of new bank." Thus, in Brazil, Russia, and India all the legal documents are mandatory to enter into the banking system. However, South Africa and China have liberalized the entry requirements post-2007. In addition, the regulators of 
TABLE 3: Definition of key regulatory indicators.

\begin{tabular}{|c|c|c|c|}
\hline Index (range) & Description & Survey questions & Quantification \\
\hline $\begin{array}{l}\text { 1. Activity } \\
\text { restrictions (4-16) }\end{array}$ & $\begin{array}{c}\text { The restriction on banks with regard to } \\
\text { insurance, securities, real estate } \\
\text { activities, and owning nonfinancial } \\
\text { firms }\end{array}$ & $\begin{array}{l}\text { Whether banks are allowed to foray into } \\
\text { insurance, securities, real estate activities, } \\
\text { and own nonfinancial firms? }\end{array}$ & $\begin{array}{c}\text { Unrestricted }=1, \\
\text { permitted }=2, \text { restricted }=3 \text {, } \\
\text { prohibited }=4 . \\
\text { Higher value indicates more } \\
\text { restrictiveness }\end{array}$ \\
\hline $\begin{array}{l}2 \text { Banks' entry } \\
\text { requirements }(0-8)\end{array}$ & $\begin{array}{l}\text { Requirements to submit legal } \\
\text { documents to get banking license }\end{array}$ & $\begin{array}{l}\text { What are the different documents required } \\
\text { to get a banking license? }\end{array}$ & $\begin{array}{l}\text { Yes }=1, \text { no }=0 \\
\text { Higher value indicates } \\
\text { greater stringency }\end{array}$ \\
\hline $\begin{array}{l}\text { 3. Restriction on } \\
\text { foreign bank entry } \\
(0-4)\end{array}$ & $\begin{array}{l}\text { Barriers to foreign bank entry into the } \\
\text { domestic banking system }\end{array}$ & $\begin{array}{l}\text { Whether the foreign banks are allowed to } \\
\text { enter by branch mode, subsidiary, joint } \\
\text { venture, or acquisition? }\end{array}$ & $\begin{array}{l}\text { Yes }=0, \text { no }=1 \\
\text { Lower value indicates } \\
\text { greater stringency }\end{array}$ \\
\hline $\begin{array}{l}\text { 4. Capital stringency } \\
(0-10)\end{array}$ & $\begin{array}{l}\text { The extent of restriction on overall } \\
\text { capital requirement }\end{array}$ & $\begin{array}{l}\text { Whether the source of fund is verified? } \\
\text { Which regulatory capital adequacy regimes } \\
\text { are being used? Category of risk enclosed by } \\
\text { the minimum capital requirements. }\end{array}$ & $\begin{array}{l}\text { Yes }=0, \text { no }=1 \\
\text { Higher values indicate } \\
\text { greater stringency }\end{array}$ \\
\hline $\begin{array}{l}\text { 5. Power of deposit } \\
\text { insurer }(0-4)\end{array}$ & $\begin{array}{l}\text { The extent to which deposit insurance } \\
\text { authority has power to intervene and } \\
\text { take legal actions }\end{array}$ & $\begin{array}{l}\text { Powers of deposit insurers to make any } \\
\text { decision, interference, and take legal action }\end{array}$ & $\begin{array}{l}\text { Yes }=1, \text { no }=0 \\
\text { Higher values indicate more } \\
\text { power }\end{array}$ \\
\hline
\end{tabular}

Source: authors' elaboration from Barth et al. [9].

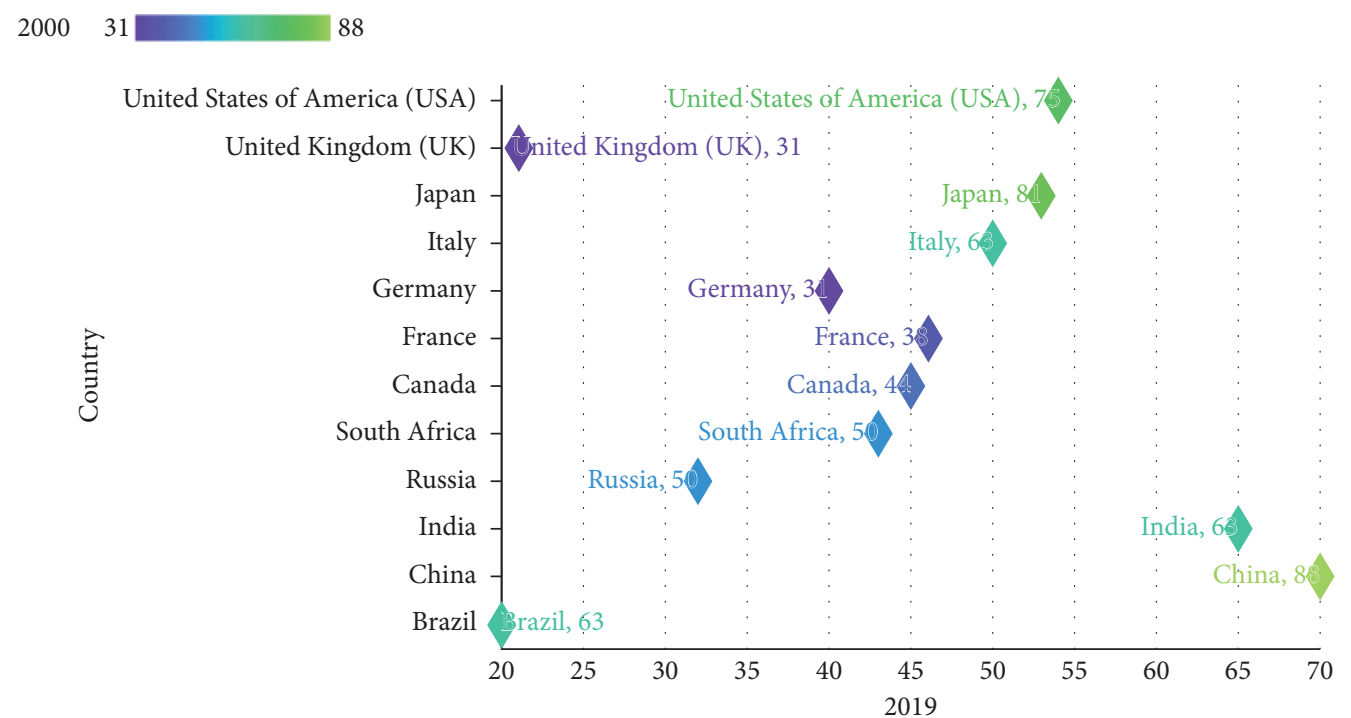

Figure 4: Activity restrictions, by country (\% of maximum score).

banking sector in the UK, Italy, and Canada ask all the eight documents to be submitted to grant a bank license. They allow "fit and proper" applicants to enter the banking industry. Germany akin to Japan is liberal to some extent with regard to the entry requirement into banking. However, they imposed the highest capital stringency norms, in order to ensure the stability of the banks (see Figure 6).

5.1.3. Restrictions on Foreign Bank Entry. This index reflects barriers on foreign bank entry into the domestic banking system. It is based on whether the foreign bank is allowed to enter by branch mode, subsidiary, joint venture, or acquisition. Furthermore, the index ranges from 0 to 4 ; higher value indicates more restrictions on foreign bank entry. Figure 7 reveals that among the BRICS nations, only Russia has never allowed entry of foreign banks into domestic banking sector by branch mode. By 2019, China, Brazil, South Africa, and India allowed foreign banks to enter by acquisition, subsidiary, branch, and joint ventures. Earlier, the South African banking sector constrained foreign bank entry by joint venture mode. However, after 2007, joint venture was also allowed to enter into the domestic banking system. Turning to G7 countries, the regulators had never imposed restrictions on foreign applicants to enter the banking sector (see Figure 5). In 2011, except Russia, all the sampled countries have allowed foreign applicants into the banking sector through all routes with no barriers. However, in the entire G7 region, the regulators put maximum restrictions on the foreign bank entry into their domestic banking system. Particularly, after the GFC 2007/08, the G7 nations have augmented the check list for outsider 


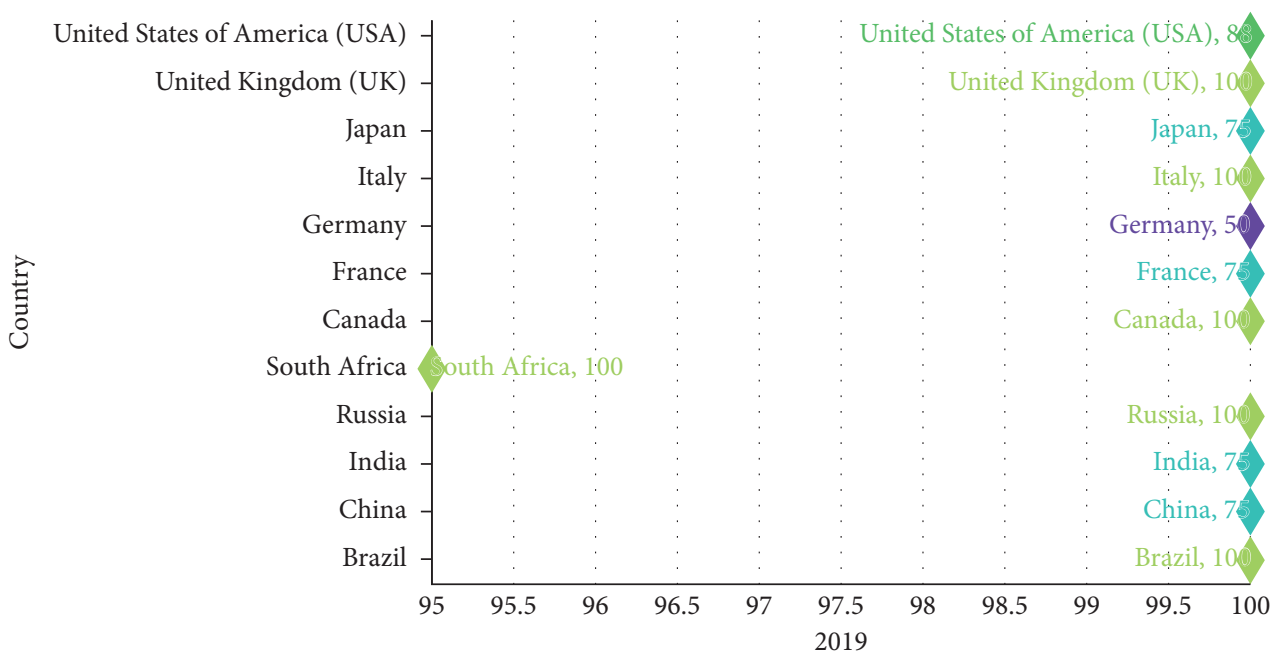

FIGURE 5: Entry requirements into banking, by country (\% of maximum score).

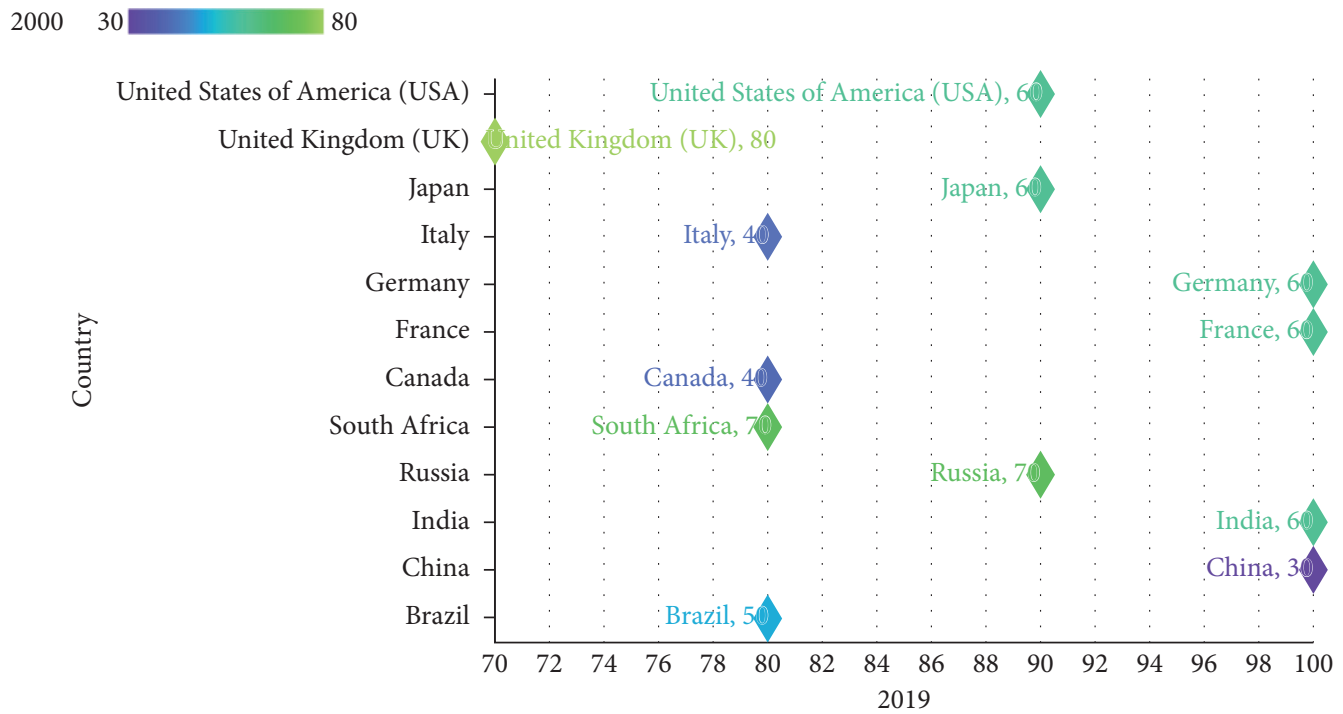

Figure 6: Capital stringency, by country (\% of maximum score).

applicants to enter inter the domestic banking sector. Moreover, the authors observe that, in order to ensure the resilience of the banking system, both the regions have increased the scrutiny of applicants letting them enter into their domestic banking.

5.1.4. Capital Stringency. Figure 8 demonstrates the overall bank capitalization in BRICS and G7 nations estimated by the capital to risk-weighted assets ratio. The banks in BRICS countries were found to be more capitalized than those in the G7 region in the early 2000s. Since 2007, the position has reversed. Within the BRICS region, Russian and Brazilian banks have been found to be more capitalized. The Chinese banking sector, which was not on par in terms of capital previously has now improved its position and is in line with global standards. In 2019, the bank capital ratio in both the regions has increased and is aligned with international standards.
Delving deeper into the capital requirement standards, the study also examines the stringency of capital requirement across the BRICS and G7 nations. An assessment of capital requirement stringency has been done using the index for stringency on capital measure for the capital requirement and its restrictions which assist in mitigating risks in the banking sector [18]. The index varies between 0 and10; higher values indicate greater stringency on capital adequacy norms. To formulate the index, the responses to some of the questions like: Whether the source of fund is verified or not? Which capital adequacy regimes are being used? Which regulatory category of risk is enclosed by the minimum capital requirements? Figure 6 reveals that restrictions on capital requirements were almost similar in both the regions in early 2000. Between the year 2003 and 2019, the capital requirements became more stringent in BRICS nations; China and India imposed greater capital restrictions in order 
2000
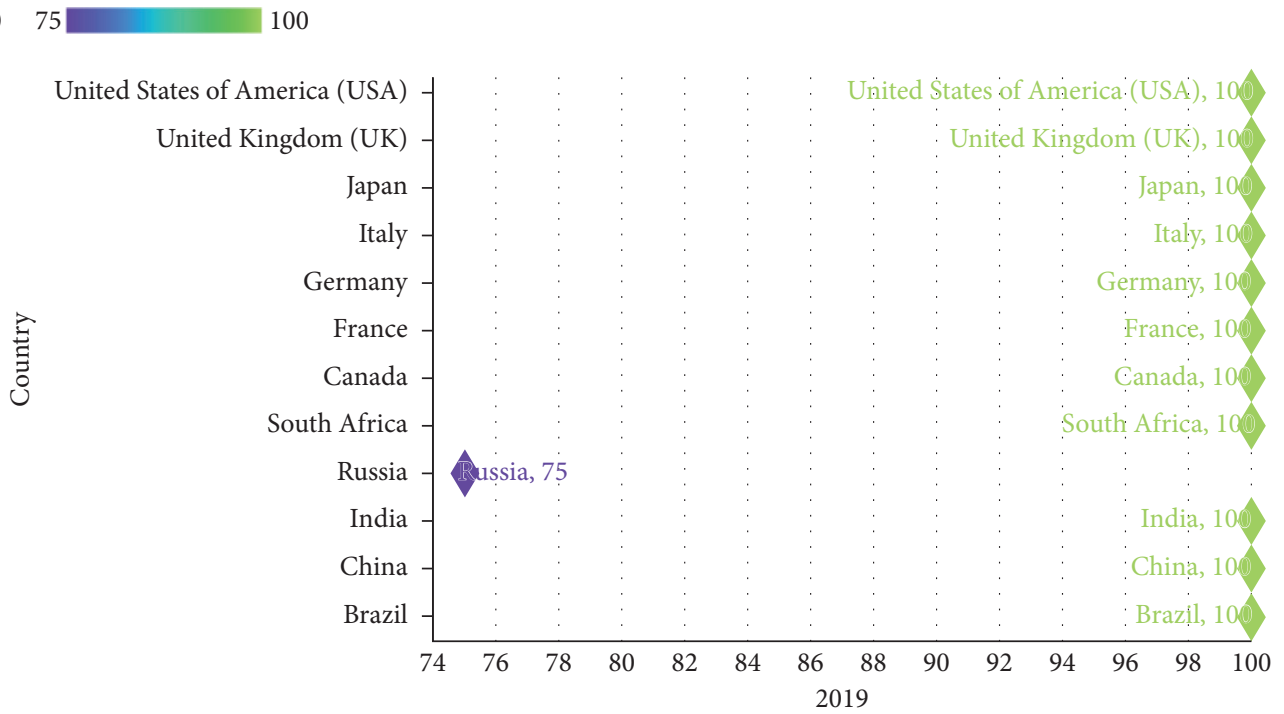

Figure 7: Restrictions on foreign bank entry, by country (\% of maximum score).

2000
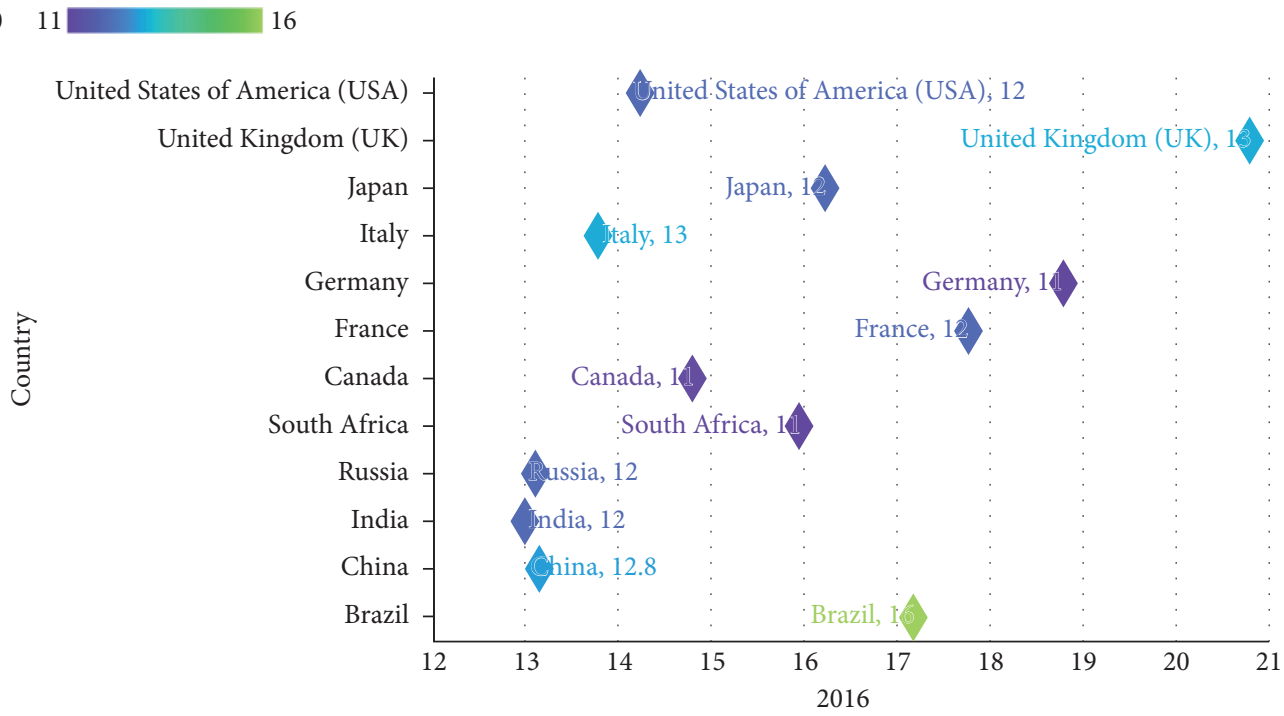

FIgURe 8: Capital to risk-weighted assets, by country (in \%).

to be aligned with the Basel III minimum capital accord, based on the market risk and credit profile of individual banks (see Figure 6). Furthermore, except UK, the G7 countries had also increased restrictions on minimum capital requirements by 2019.

The regulators of the entire BRICS region first verify capital source which is going to be part of bank capital. Except the Brazilian regulator, borrowed fund for initial capital requirement by shareholders is not allowed. In addition, assets other than cash and government securities are allowed in Russia and South Africa to be the part of the initial and subsequent capital requirement. Over the period, G7 nations increased capital restrictions. The entire G7 region allowed initial capital injections other than cash or government securities, with Canada, Italy, United Kingdom, and United States allowing borrowed funds. French regulators restricted the capital stringency after 2003. In recent years, the United Kingdom has liberalized capital requirements. The results suggest that both the regions follow a different kind of strategy. In the initial years, restrictions on capital requirements were almost at the same level, but in more recent years, the BRICS nations have made capital requirements more stringent by following the Basel II and III accords, compared to G7 countries.

5.1.5. Power of Deposit Insurer. Deposit insurance schemes protect the depositors in the case of a bank run. These schemes act as a safety net of a country's financial system and ensure the high confidence in the banking sector. Furthermore, the effectiveness of deposit insurance schemes depends upon the powers of deposit insurers. Following Barth el al. [17], the index for deposit insurer power is constructed to measure the degree of various 
powers with the authority related to deposit insurance. These powers are: to take legal actions against banks officials, to intervene in the banking system, and to cancel the deposit insurance scheme of the particular bank if found guilty.

Figure 9 reflects that the deposit insurance authorities have greater powers in G7 countries, compared to BRICS nations. The authorities in the BRICS region have much less powers to take legal action against violation of law, or to cancel the insurance scheme (deposit) of a particular guilty bank. In the Indian banking system, the Deposit Insurance and Credit Guarantee Corporation (DICGC) has the power to cancel the insurance of deposits if the bank is found to be guilty. Recently, the Russian regulators also permitted the deposit insurance organizations to intervene in bank decisions and revoke the insurance for a bank. On the other hand, Canada and United States have very powerful deposit insurance regulatory authority (see Figure 6). Furthermore, the index value reveals no significant improvement in the deposit insurance system across BRICS countries. Thus, the deposit insurance schemes in the BRICS region are not welldesigned, and evidences reveal a structure with insufficient deposit insurer power and inadequacy of factors to mitigate moral hazards. Furthermore, the USA has a very welldesigned deposit insurance mechanism and the regulator empowers the deposit insurers with more powers and independence. However, in sum, both the regions have to emphasize more on deposit insurance schemes and grant more powers to deposit insurers.

5.2. Convergence in Regulatory Standards in BRICS to G7 Norms. To assess the convergence in the regulatory adequacy framework among BRICS and G7 nations, the study compares the regional weighted averages of selected regulatory indices in the year 1999 to 2019 of both the regions. The authors have prepared a radar chart based on the selected regulatory indicators for the regions and tested for the convergence. From Figure 10, the study observes a weak convergence in the restrictions on bank activities over time. While the BRICS weighted average for activity restrictions have moved up gradually over the period and declined in 2019, the weighted average of the G7 region declined over the period, and moved upward in 2019, converging on the former. However, there are clear differences in the scope of bank activities in each region. This indicates that one size may not fit all. More recently, it has been observed that the future trend in new banking reforms is moving toward more restrictions in G7 nations, while reforms in BRICS nations are moving toward liberalizing the restrictions on bank activities.

Next, the results depict the convergence in entry requirements into banking. The bank regulators in the BRICS and the G7 region have made licensing requirements more stringent over time. Almost all standard requirements for entry into banking have been made mandatory in the BRICS region, except China and South Africa. This is to improve the financial health and maintain systemic stability in the banking system by allowing only "fit and proper" applicants into banking. Furthermore, the entry norms for foreign banks' entry into BRICS region seem to have converged to G7 norms indicating the convergence phenomenon. On comparing the stringency of capital requirements, the study does not identify any convergence. Both the regions follow different strategies; BRICS nations have made capital requirement more stringent to ensure financial stability by following the Basel I, II, and III accords. Banks in G7 nations are more capitalized than BRICS, but have fewer restrictions on the initial capital stringency.

The study reveals some weaknesses in the deposit insurance system of BRICS nations as compared to G7 nations. Deposit insurance authorities in G7 nations have more powers to intervene and take legal actions against bank officials in violation of laws. However, in the BRICS region, the deposit protection system is not well framed and may lead to moral hazard problems and the insurer cannot revoke insurance (except in India). The study does not advocate convergence in the practices to protect depositors' interest in the BRICS region to the international standards. Finally, the study found that, in both the regions, the regulatory authorities have delegated more powers to supervisors over time, which reflects that the official supervisory power with the BRICS nations are not far from the bestpractices defined by the G7 nations.

Moreover, the study observes a strong convergence in terms of fulfillment of entry licensing requirements for a new bank and relaxing limitations on the entry of foreign banks. However, a weak convergence is reported for activity restrictions. In early 2000s, there were the same standards of capital requirements in both the regions; but in 2019, BRICS has increased stringency on capital requirements following Basel II and III accords, compared to G7 nations. This has increased the disparities in capital requirements between the regions. Furthermore, the BRICS nations still have weaknesses in the deposit insurance schemes. Although to a lower degree, the power of the official supervisors to restructure or declare banks as insolvent has been found to be similar in both the regions in 2019.

\section{Discussion}

The main idea of conducting this research is to examine the development of regulations and supervisory mechanism in BRICs and G7 nations. In addition, the present article also tries to scrutinize the convergence of regulatory practices in BRICs nations with G7 counterparts. Following the Barth et al. [17] guidelines, the study constructed the five key regulatory and supervisory indexes pertaining to (i) activity restrictions, (ii) bank entry requirements, (iii) restrictions on foreign bank entry, (iv) capital adequacy norms, and (v) powers of the deposit insurer based on the responses to the Bank Regulatory and Supervisory Survey (BRSS) conducted by the World Bank.

The study finds that in the BRICS region, China and India imposed more restrictions on bank activities. However, Russian and Brazilian regulators were more liberal. Higher restriction on bank activities may hamper the bank diversification strategies [41]. Usually, the organizations diversify 


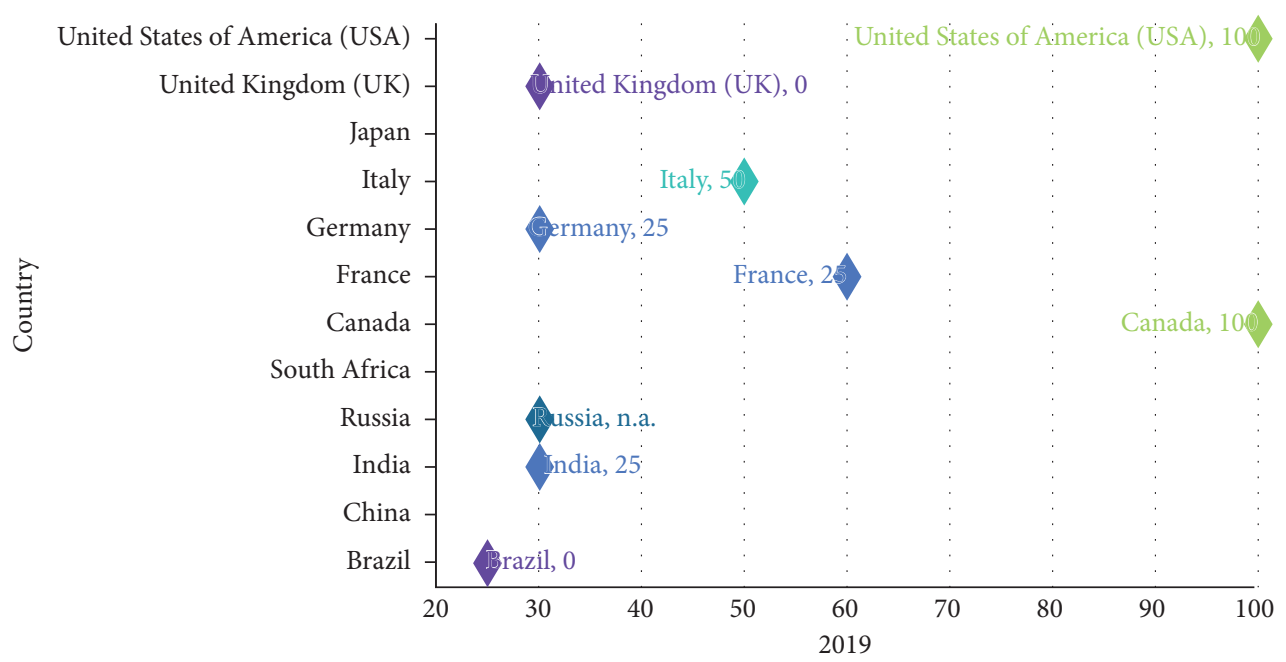

FIGURE 9: Deposit insurer power, by country (\% of maximum points).
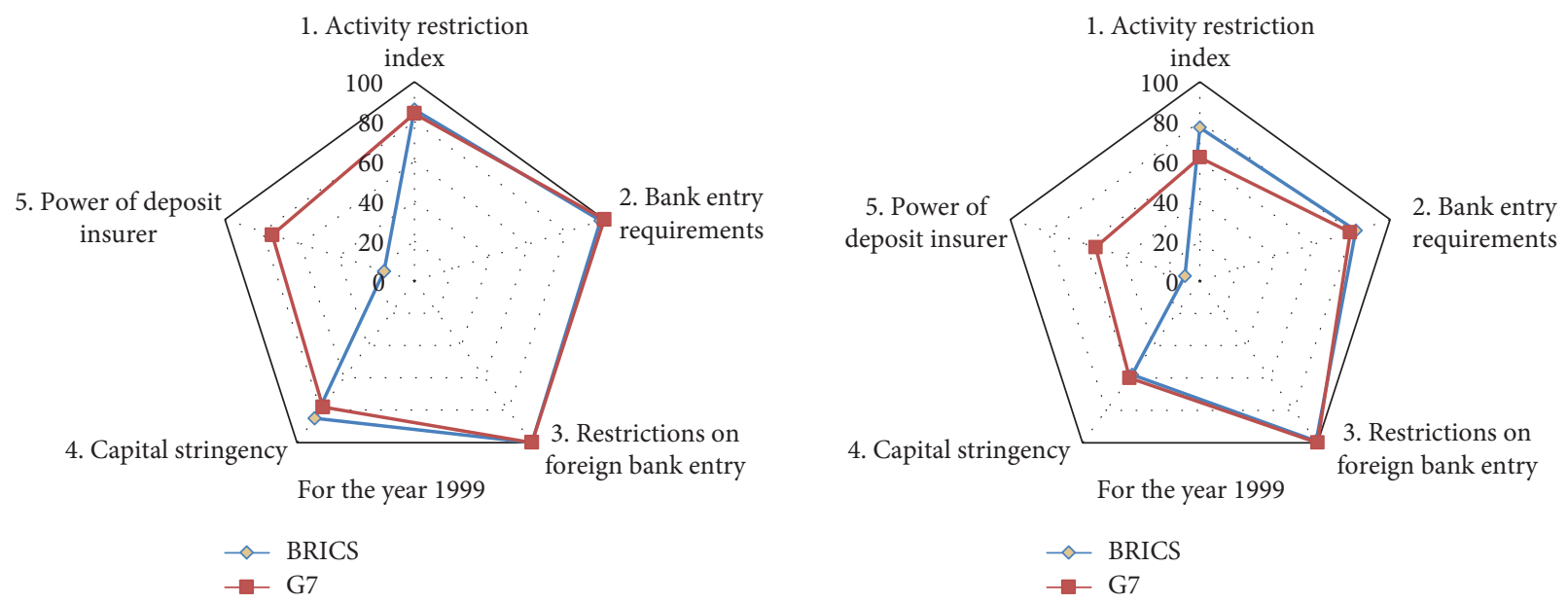

Figure 10: Convergence in regulatory standards in BRICS to G7 norms from 1999 to 2019.

their business revenue in order to mitigate the operating risk. Furthermore, the findings are supported by the observations noted by Barth et al. [9]. They argue that income diversification increases the bank stability and firm performance. Furthermore, the higher regulation on bank activity may negatively impact the competitive environment in the industry [41]. Therefore, higher restriction on bank activities may reflect the competition level in the particular country. The authors may conclude that Indian and Chinese banking systems are less competitive than Russia and Brazil. Our observations are in line with Moudud-Ul-Huq [48] who finds that the BRICS banking sector is less competitive due to less financial freedom and greater financial restrictions. In the case of India, the real sate activities are strictly prohibited to exclude the risk of fragility. Furthermore, the US Banking sector is the most regulated, and the regulatory body does not allow banks to engage in real estate activities. In addition, the study concludes that the US banking system is more stable and less competitive. The findings are in agreement with Solano's [49] observations that highlighted the association between the robustness of US banking system and rivalry level. Furthermore, the study reports that the UK banking sector is the least restricted. The regulators put few restrictions on insurance activities only. In sum, the banking sector in UK is more liberal. The banks in UK also earn revenue from the nonfinancial domain as well. Furthermore, our findings are supported by Yin [30] who argues that the developing countries imposed more restrictions on bank activities than developed nations. The author also cites that the weaker supervisory mechanism in developing nations is one of the key factors behind the more number of restrictions on bank activities. Furthermore, the study concludes the convergence in the bank activity restriction in both the regions.

In addition, the entry and exit policies in the banking industry also affect the level of competition and stability in the banking sector. Furthermore, the bank entry restrictions may hamper the competitive environment and lead to lower performance [41]. Entry into banking is tough in the G7 
nations. They allow only fit and proper applicants into the banking system. The bank regulators in the BRICS and G7 countries have made licensing requirements more stringent over time. Furthermore, the study finds convergence in the bank entry requirements. This is to improve the financial health and maintain the stability in the banking system by allowing only financially sound candidates to enter the banking sector. The regulator also imposed restrictions on foreign bank entry into the domestic banking sector in order to ensure stability and healthy competition. Similar observations have been reported by Li [25]. The lower restriction on the entry of foreign banks and liberal environment for bank activities lead to better competition in the banking sector [40]. Post-GFC, China and South Africa have liberalized the entry requirement into banking; this could have increased the competition level in both the countries. Moreover, to validate the statement, interested researchers may further extend the work to analyze the association between entry regulation and the level of competition. Although bank entry is not legally restricted in G7 and BRICS nations, rejections may be due to the reputation of the applicant, discrepancy in documents, inappropriate ownership structure, and lack of deposit insurance. Moreover, bank entry requirement in BRICS has become liberalized over time and similar observations were reported by Gulati [41].

Furthermore, a well-capitalized bank is considered to be the stable and financially sound. In addition, capital supervision is one of the significant tools to control the risktaking behavior of banks [50]. Therefore, regulators intentionally imposed higher restrictions of bank requirements as well as its structure and formation. Earlier the banks in BRICS were well capitalized. However, recently, the G7 banks are found to be more capitalized. In addition, instances of bank defaults are less in the G7 countries, thanks to the rigorous capital requirement [42]. Recently, the bank capital ratio in both the regions has increased and is aligned with international standards. In particular, the Russian and Brazilian banks have been found to be more capitalized. In addition, China and India imposed greater capital restrictions in order to be aligned with the Basel III minimum capital accord, based on the market risk and credit profile of individual banks. Furthermore, the regulators in G7 nations are more concerned and monitor for compliance and capitalization requirement.

Deposit insurance schemes protect the depositors in case of a bank run. These schemes act as a safety net of a country's financial system and ensure the high confidence in the banking sector. However, at the same time, they may create moral hazards issue by reducing the incentives for the depositors to scrutinize the banks. In addition, they also induce the shareholders to take excessive risky decisions. The literature reported a mix of arguments about the deposit insurance schemes [14, 42].

Furthermore, among G7 nations, the US banking system was the first to establish an explicit deposit insurance system in 2011. Only Italy and UK have ex-post deposit insurance schemes (i.e., the premium fund to be collected on the occurrence of bank failure). While all other countries follow ex-ante insurance schemes, the premium for deposit insurance is risk-adjusted in Canada, France, Italy, and US. Finally, the burden of finance is also borne solely by banks in advanced nations. In sum, significant variations exist in the deposit insurance systems adopted by the emerging and advanced nations [14]. In order to minimize the moral hazard issues and maximize the welfare of depositors, the financial regulators must be equip the deposit insurer with more powers and independence. The empirical results suggest that the deposit insurers in G7 nations are more powerful than those in the BRICS region. The authorities can take legal action or cancel the insurance policy of banks in case the bank is found guilty. Furthermore, the welfare of depositors can be raised further by implementing appropriate deposit insurance mechanism and granting more powers to the insurer.

\section{Conclusions and Policy Implications}

The study aimed to examine the regulatory conduct of the banking sector, particularly in the BRICS countries, namely, Brazil, Russia, India, China, and South Africa during the period 2000-2019. The regulatory gaps have been ascertained by equating the regulatory and supervisory practices adopted in BRICS vis-à-vis G7 countries. The study measured the regulatory indexes of five selected regulatory dimensions using the responses from World Bank's BRSS survey and deploying Barth et al.'s [17] guidelines.

Based on the findings, the study concludes that the regulatory framework in BRICS nations is moving toward global standards by delegating more powers to the supervisors. In particular, the BRICS banking sector imposes more restrictions on banking activities than G7 nations. The study suggests that regulators must allow banks to enter into nonbanking activities with more monitoring and supervision, which will further enable banks to diversify their revenue and enhance their profitability. Furthermore, the policy-makers and regulators need to impose more checks of the entry of new banks into the sector in order to enhance the stability of the financial system. Moreover, in order to promote healthy rivalry in the banking sector, the regulator may put eyes on price determination, products and offering, and other lending terms of the banks. In addition, to stimulate competition along with better stability in the industry, regulators need to increase the monitoring on foreign bank entry and allow only "fit and proper" applicants into the banking system. The literature has established the relationship between bank capitalization and its stability. Therefore, regulators must maintain the level of stringency of bank capital and monitor regularly to ensure the robustness of the banking system. Furthermore, the despot insurance system is found to be less equipped with decisionmaking powers in the BRICS nations. The study suggests that the regulators must strengthen the deposit insurers' powers in order to protect the depositor's interest and increase their welfare. Furthermore, the appropriate deposit insurance mechanism also helps in reducing the moral hazards issue in the banking sector which ultimately stimulates the shareholders for responsible investment. Allowing 
banks to diversify their activities with proper monitoring, granting entry after in-depth scrutiny of the applicants, and additional stringency on bank capital along with enriching the powers of the deposit insurer transform the banking sector into an efficient and resilient one. The efficient and financially robust banking system boosts the economic development of the nations.

\section{Limitations of the Study and Directions for Future Research}

This study has used selected regulator and supervisory indicators to examine the banking system. In addition, the study did not assess the impact of regulation on banks' profitability, stability, competition, or risk-taking behavior. Interested authors may further extend this study by analyzing the additional dimensions of regulatory and supervisory practices in the banking system. In addition, association between the regulatory dimensions and banks' performance may be examined by the interested authors. Furthermore, the entry requirements or foreign bank entry restrictions may be linked with the competition levels in the banking sector.

\section{Data Availability}

The authors have formulated the various regulatory and supervisory indexes based on the responses of five rounds of World Bank Survey: Bank Regulation and Supervision Survey. The responses of all the five surveys are available in the public domain: World Bank database, https://www.worldbank.org/ en/research/brief/BRSS. The Bank Regulation and Supervision Survey is a unique source of comparable economy-level data on how banks are regulated and supervised around the world, and the data are publicly available.

\section{Additional Points}

The study conducted a search on "Scopus" database, which is trusted across the globe and contains a wide variety of research. The study used the following command: (TITLEABS-KEY ("Bank regulation and supervision") OR TITLEABS-KEY ("Bank regulation and supervision survey") OR TITLE-ABS-KEY ("Bank regulation") OR TITLE-ABS-KEY (“BRSS Survey")) AND (LIMIT-TO (DOCTYPE, “ar")) AND (LIMIT-TO (SUBJAREA, "ECON") OR LIMIT-TO (SUBJAREA, "BUSI") OR LIMIT-TO (SUBJAREA, "SOCI") OR LIMIT-TO (SUBJAREA, "DECI") ) AND (LIMIT-TO (LANGUAGE, "English")) and found 733 articles published during the years 1971 to 2021 . The authors have limited their search to Journal Articles published in the English Language in Economics, Econometrics and Finance, Business Management and Accounting, Social Sciences, and Decision Sciences domain only.

\section{Conflicts of Interest}

The authors declare that there are no conflicts of interest regarding the publication of this article.

\section{Acknowledgments}

The authors are also grateful to Mrs. Saba Shireen for providing constructive feedback and Dr. Mansour Saleh Albarrak (Dean, College of Administrative \& Financial Studies, SEU) and Dr. Yusuf N Akil (HoD, Department of Finance \& Economics, SEU) for their wonderful leadership and encouraging attitude toward research. Moreover, authors are solely responsible for the remaining errors.

\section{References}

[1] D. Anginer, A. C. Bertay, C. Robert, A. K. Demirguc, and S. M. Davide, "Bank regulation and supervision ten years after the global financial crisis," in Policy Research Working PaperInternational Monetary Fund, Washington, DC, USA, 2019.

[2] M. Čihák, A. K. Demirgüç, M. S. P. Martínez, and A. C. Mohseni, "Bank regulation and supervision around the World: a crisis update," in World Bank Policy Research Working Paper 6286, World Bank, Washington, DC, USA, 2012.

[3] K. Djalilov and J. Piesse, "Bank regulation and efficiency: evidence from transition countries," International Review of Economics \& Finance, vol. 64, pp. 308-322, 2019.

[4] N. Gunningham, "A quiet revolution: central banks, financial regulators, and climate finance," Sustainability, vol. 12, no. 22, 2020.

[5] C. L. Gutiérrez and J. A. González, "Sustainability in the banking sector: a predictive model for the European banking union in the aftermath of the financial crisis," Sustainability, vol. 12, 2020.

[6] M. Fratzscher, P. J. König, and C. Lambert, "Credit provision and banking stability after the great financial crisis: the role of bank regulation and the quality of governance," Journal of International Money and Finance, vol. 66, pp. 113-135, 2016.

[7] A. Maredza, P. Wanke, J. Antunes, R. Pimenta, and T. Yong, "Social welfare and bank performance: evidence from a stochastic neural hybrid MCDM approach," Journal of Economics Studies, 2021, In press.

[8] R. Stewart, M. Chowdhury, and V. Arjoon, "Bank stability and economic growth: trade-offs or opportunities?" Empirical Economics, vol. 61, no. 2, pp. 827-853, 2021.

[9] J. R. Barth, G. Caprio, and R. Levine, "Bank regulation and supervision: what works best?" Journal of Financial Intermediation, vol. 13, no. 2, pp. 205-248, 2013.

[10] BIS Annual Report 2021, Bank for International Settlement, Promoting Global Monetary and Financial Stability, BIS, Switzerland, 2021.

[11] Global Financial Development Report 2019, Bank Regulation and Supervision a Decade after the Global Financial Crisis, World Bank Group, Washington, DC, USA, 2019, https:// openknowledge.worldbank.org/handle/10986/32595.

[12] D. Anginer, A. C. Bertay, R. Cull, A. K. Demirguc, and D. S. Mare, Bank Regulation and Supervision Ten Years after the Global Financial Crisis, World Bank, Washington, DC, USA, 2019, https://openknowledge.worldbank.org/handle/ 10986/32589.

[13] World Development Report, Trading for Development in the Age of Global Value Chain A World Bank Flagship Report, World Bank, Washington, DC, USA, 2020, https:// openknowledge.worldbank.org/handle/10986/32437. 
[14] R. Ayadi and W. P. D. Groen, "Banking and insurance in the GCC countries: is there regulatory convergence with the EU?" in Bridging the Gulf: EU-GCC Relations at a Crossroads, vol. 89, Edizioni Nuova Cultura, Rome, Italy, 2013, http:// www.sharaka.eu/wp-content/uploads/2013/07/Sharaka_RP_ 04.pdf.

[15] G. E. Chortareas, C. Girardone, and A. Ventouri, "Bank supervision, regulation, and efficiency: evidence from the European Union," Journal of Financial Stability, vol. 8, no. 4, pp. 292-302, 2012.

[16] T. Triki, I. Kouki, M. B. Dhaou, and P. Calice, "Bank regulation and efficiency: what works for Africa?" Research in International Business and Finance, vol. 39, pp. 183-205, 2017.

[17] J. R. Barth, C. Lin, Y. Ma, J. Seade, and F. M. Song, "Do bank regulation, supervision and monitoring enhance or impede bank efficiency?" Journal of Banking \& Finance, vol. 37, no. 8, pp. 2879-2892, 2013.

[18] R. Ayadi, E. Arbak, and W. P. D. Groen, Convergence and Integration of Banking Sector Regulations in the Euro-Mediterranean Area (No. 7853), Centre for European Policy Studies, Belgium, 2013, http://www.medpro-foresight.eu/system/files/MEDPRO\% 20TR\%20No\%2034\%20WP6\%20Ayadi.pdf.

[19] G. Ambrocio, I. Hasan, E. Jokivuolle, and K. Ristolainen, "Are bank capital requirements optimally set? Evidence from researchers' views," Journal of Financial Stability, vol. 50, Article ID 100772, 2020.

[20] S. Li and X. Li, "Bank competition, regulation, and efficiency: evidence from the Asia-Pacific region," Asia-Pacific Journal of Accounting \& Economics. pp. 1-28, 2021, In press.

[21] J. R. Barth, G. Caprio, and R. Levine, The Regulation And Supervision Of Banks Around The World: A New DatabaseWorld Bank, Washington, DC, USA, 2001.

[22] A. K. Demirgüç-Kunt and E. Detragiache, "Does deposit insurance increase banking system stability? An empirical investigation," Journal of Monetary Economics, vol. 49, no. 7, pp. 1373-1406, 2002.

[23] D. Anginer, A. C. Bertay, R. Cull, A. K. Demirgüç, D. S. Mare, and S. M. Davide, "Bank capital regulation and risk after the global financial crisis," Journal of Financial Stability, 2021, In press, Article ID 100891.

[24] M. Noor, H. Haziaton, M. H. Bakri, W. Y. R. Yusof, R. S. M. N. Mohd, and N. Zainal, "The impact of the bank regulation and supervision on the efficiency of Islamic Banks," The Journal of Asian Finance, Economics, and Business, vol. 7, no. 11, pp. 747-757, 2020.

[25] S. Li, "Bank competition, regulation, and efficiency, contributions to finance and accounting," in Financial Regulation and Bank Performance, pp. 133-178, Springer, Singapore, 2021.

[26] V. Dudchenko, T. Goncharenko, O. Didenko, and T. Olejarz, "Banking regulation in ensuring bank's efficiency: looking through different forms of ownership," Journal of International Studies, vol. 13, no. 1, pp. 342-358, 2020.

[27] H. Hakenes and I. Schnabel, "Capital regulation, bank competition, and financial stability," Economics Letters, vol. 113, no. 3, pp. 256-258, 2011.

[28] H. Degryse and S. Ongena, "Competition and regulation in the banking sector: a review of the empirical evidence on the sources of bank rents," Handbook of Financial Intermediation and Banking, pp. 483-554, 2008.

[29] M. E. K. Agoraki, G. P. Kouretas, and C. Triantopoulos, "Democracy, regulation and competition in emerging banking systems," Economic Modelling, vol. 84, pp. 190-202, 2020 .
[30] H. Yin, "The impact of competition and bank market regulation on banks' cost efficiency," Journal of Multinational Financial Management, vol. 61, Article ID 100677, 2021.

[31] E. B. Anarfo, J. Y. Abor, and K. A. Osei, "Financial regulation and financial inclusion in Sub-Saharan Africa: does financial stability play a moderating role?" Research in International Business and Finance, vol. 51, Article ID 101070, 2020.

[32] G. Schnabl and N. Sonnenberg, Monetary Policy, Financial Regulation and Financial Stability: A Comparison between the Fed and the ECB, Universität Leipzig, Leipzig, Germany, 2020.

[33] N. Fraccaroli, R. Sowerbutts, and A. Whitworth, Does Regulatory and Supervisory Independence Affect Financial Stability? Bank of England, London, UK, 2020.

[34] L. M. Brandao, R. Correa, and H. Sapriza, "Government support, regulation, and risk taking in the banking sector," Journal of Banking \& Finance, vol. 112, Article ID 105284, 2020.

[35] J. Bartholdy and L. G. Justesen, "Can strong capital regulation prevent risk-taking from deposit insurance?" The European Journal of Finance, vol. 27, no. 12, pp. 1164-1185, 2021.

[36] A. Louhichi, S. Louati, and Y. Boujelbene, "The regulationsrisk taking nexus under competitive pressure: what about the Islamic banking system?" Research in International Business and Finance, vol. 51, Article ID 101074, 2020.

[37] J. Hilscher, Y. Landskroner, and A. Raviv, "Optimal regulation, executive compensation and risk taking by financial institutions," Journal of Corporate Finance, vol. 71, Article ID 10204, 2021, In press.

[38] J. R. Barth, G. Caprio, and R. Levine, Rethinking Bank Regulation: Till Angels Govern, Cambridge University Press, Cambridge, UK, 2008.

[39] A. K. Demirgüç-Kunt and M. S. P. Martínez, A Framework for Analyzing Competition in the Banking Sector: An Application to the Case of Jordan, World Bank Policy Research Working Paper, Washington, DC, USA, 2010, https://pdfs. semanticscholar.org/f1e3/ e459a61430adcc37e3e62a9155661cccef71.pdf.

[40] S. Li, "The impact of bank regulation and supervision on competition: evidence from emerging economies," Emerging Markets Finance and Trade, vol. 55, no. 10, pp. 2334-2364, 2019.

[41] R. Gulati, "Demystifying gaps and testing for convergence in bank regulations impacting the competitive environment: a case of India and its peers in BRICS," Journal of Financial Regulation and Compliance, vol. 29, no. 1, pp. 15-43, 2021.

[42] B. N. Ashraf, C. Zheng, C. Jiang, N. Qian, and N. Qian, "Capital regulation, deposit insurance and bank risk: international evidence from normal and crisis periods," Research in International Business and Finance, vol. 52, Article ID 101188, 2020.

[43] H. Yin, "Foreign bank entry and bank competition: cross-country heterogeneity," Global Finance Journal, vol. 48, Article ID 100558, 2021.

[44] E. Carletti, R. Marquez, and S. Petriconi, "The redistributive effects of bank capital regulation," Journal of Financial Economics, vol. 136, no. 3, pp. 743-759, 2020.

[45] Z. He and G. Qiao, L. Zhang and W. Zhang, Regulator supervisory power and bank loan contracting," Journal of Banking \& Finance, vol. 126, Article ID 106062, 2021.

[46] I. Avgeri, Y. Dendramis, and H. Louri, "The Single Supervisory Mechanism and its implications for the profitability of European banks," Journal of International Financial Markets, Institutions and Money, vol. 74, Article ID 101382, 2021. 
[47] X. Zhang, C. Wei, and S. Zedda, "Analysis of China commercial banks' systemic risk sustainability through the leaveone-out approach," Sustainability, vol. 12, 2020.

[48] S. Moudud-Ul-Huq, "Does bank competition matter for performance and risk-taking? empirical evidence from BRICS countries," International Journal of Emerging Markets, vol. 16, no. 3, pp. 409-447, 2020

[49] J. Solano, S. M. Camino, and G. B. Armijos, "Intra-banking competition in Ecuador: new evidence using panel data approach," Journal of Economics, Finance and Administrative Science, vol. 25, no. 50, pp. 295-319, 2020.

[50] W. Wang, J. Zhang, and Y. Wang, "Capital supervision, information disclosure and risk-taking-evidence from rural commercial banks in China," Emerging Markets Finance and Trade, 2021, In press. 